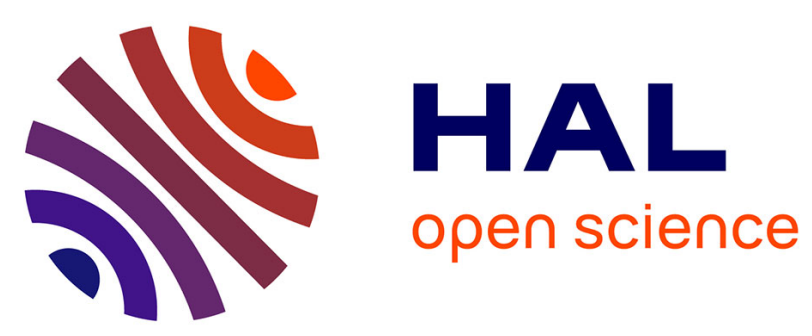

\title{
A scientific note on diploid males in a reproductive event of a eusocial bee
}

Charles Santos, Cristiano Menezes, Vera Imperatriz-Fonseca, Maria Arias

\section{To cite this version:}

Charles Santos, Cristiano Menezes, Vera Imperatriz-Fonseca, Maria Arias. A scientific note on diploid males in a reproductive event of a eusocial bee. Apidologie, 2013, 44 (5), pp.519-521. 10.1007/s13592013-0202-0 . hal-01201322

\section{HAL Id: hal-01201322 \\ https://hal.science/hal-01201322}

Submitted on 17 Sep 2015

HAL is a multi-disciplinary open access archive for the deposit and dissemination of scientific research documents, whether they are published or not. The documents may come from teaching and research institutions in France or abroad, or from public or private research centers.
L'archive ouverte pluridisciplinaire HAL, est destinée au dépôt et à la diffusion de documents scientifiques de niveau recherche, publiés ou non, émanant des établissements d'enseignement et de recherche français ou étrangers, des laboratoires publics ou privés. 


\title{
A scientific note on diploid males in a reproductive event of a eusocial bee
}

\author{
Charles Fernando dos SAntos $^{1,2}$, Cristiano Menezes $^{3}$, Vera Lucia Imperatriz-Fonseca ${ }^{2,4}$, Maria Cristina Arias ${ }^{5}$ \\ ${ }^{1}$ Departamento de Zoologia, IB, Universidade de São Paulo, Rua do Matão, 321, Travessa 14, \\ 05508-090 São Paulo, SP, Brazil \\ ${ }^{2}$ Laboratório de Abelhas, Departamento de Ecologia, IB, Universidade de São Paulo, Rua do Matão, 321 , \\ Travessa 14, 05508-090 São Paulo, SP, Brazil \\ ${ }^{3}$ Empresa Brasileira de Pesquisa Agropecuária-Amazônia Oriental, travessa Dr. Enéas Pinheiro, s/n, \\ 66095-105 Belém, PA, Brazil \\ ${ }^{4}$ Universidade Federal Rural do Semiárido, Km 47-BR110, Mossoró, RN, Brazil \\ ${ }^{5}$ Departamento de Genética e Biologia Reprodutiva, IB, Universidade de São Paulo, Rua do Matão 277, \\ 05508-090 São Paulo, Brazil
}

Received 2 October 2012 - Revised 18 January 2013 - Accepted 30 January 2013

\section{bees / diploid / male / Hymenoptera / inbreeding}

In Hymenoptera (ants, wasps, bees), sex determination is controlled by haplodiploidy, with fertilized eggs giving rise to diploid females and unfertilized eggs to haploid males (Whiting 1943; Cook and Crozier 1995). However, sex determination also depends on the combination of alleles at the complementary sex determination locus (CSD). It has been demonstrated that diploid individuals but homozygous at CSD emerge as diploid males, and such individuals are likely sterile (Whiting 1943; Cook and Crozier 1995). However, it has been shown that in several Hymenoptera species, the diploid males are able to mate and generate female offspring, albeit triploid (Liebert et al. 2004; Cournault and Aron 2009; Darvill et al. 2012).

Corresponding author: C.F. Santos, chasantos@usp.br Manuscript editor: James Nieh
Hence, bee populations could be severally affected due the role of diploid male vortex in leading nest and population extinction (Zayed and Packer 2005).

In eusocial stingless bees (Meliponini), for example, diploid male production may be significant, c.a. $50 \%$ of the nest population (Alves et al. 2011; Francini et al. 2012), and queens producing diploid males, as well as themselves, are supposed to be eliminated by the workers (Alves et al. 2011; Francini et al. 2012). Thereby, diploid males in reproductive events, i.e., outside nest, have never been documented in stingless bees (Paxton 2000; Cameron et al. 2004; Kraus et al. 2008). Sexually mature stingless bees males, 23 weeks old after emerging, permanently abandon their nests and vague in environment to search for receptive females (van Veen et al. 1997). The rendezvous sites in stingless bee species involve two mating strategies. The strategy that occurs for mostly of the genera (e.g., Tetragonisca) is the congregation of tens to hundreds of males outside the nest entrance (Nogueira-Neto 1954; Kerr et al. 
1962; van Veen and Sommeijer 2000). The other known strategy occurs in Melipona species where males aggregate on non-nest associated congregation sites (Sommeijer and Bruijn 1995). In both cases, gynes do one single nuptial flight and as a rule, mating with only one male (Kerr et al. 1962; Peters et al. 1999). Here, we describe the finding of adult diploid males of Tetragonisca angustula (Latreille 1811) in reproductive aggregation beside the nest entrance.

The study was conducted at the campus of Universidade de São Paulo, in Ribeirão Preto, Brazil. The campus possesses a large number of Meliponini nests of several species. A recent inventory registered more than $250 \mathrm{~T}$. angustula nests encompassing feral and managed colonies (Soares, unpublished data). To study male aggregations in nests foundations, several trap nests were distributed around the campus. During a period of 3 weeks, five male aggregations were studied. The aggregations were set near the nests being prepared by workers to receive a new swarm. A total of 378 males from the five aggregations were collected for molecular analysis.

Total DNA was extracted from the thorax of each male through Chelex method (Walsh et al. 1991). Six microsatellite loci were used for genotyping (Brito et al. 2009): Tang03, Tang11, Tang12, Tang57, Tang60, and Tang65. Allele calling was performed in an automatic sequencer ABI 3730 at CEGH-IB-USP, using the program GeneMaker ${ }^{\circledR}$ 2.2. The allele number per locus ranged from 7 to 28 . The average allele number per locus was $9.8 \pm 0.901$ and the effective allele number was $5.2 \pm 0.613$.

It was verified that among the 378 males analyzed, two were diploid (Table I). To confirm the gender of these two individuals, their genitalia were analyzed. Also, another PCR run for each locus was performed. Both additional analyses confirmed the gender and genotypes. KinGroup 2 (Konovalov et al. 2004) was used to run a sibship reconstruction analysis, using all male genotypes and 100,000 pairwise simulations to test the sibling hypothesis based on a pairwise likelihood ratio. The analysis revealed that the two diploid males were not related $(p>0.05)$; consequently, it is possible that at least two colonies produced diploid males at that moment.

The fact that diploid males were found in reproductive aggregations is an indicative that they escaped from worker recognition. Although there is some evidence that stingless bee workers eliminate diploid males (Francini et al. 2012), there is also evidence that their chemical cuticle profile is very similar to the haploid males, at least soon after emergence (Borges et al. 2012). Whether the diploid males of T. angustula can be chemically recognized is still an opened question to be investigated. Besides, it has already been demonstrated for some species of Meliponini that several unrelated nests contribute to the same male aggregation (Paxton 2000; Cameron et al. 2004; Kraus et al. 2008) thereby decreasing the possibility of the queen mating with related males.

The presence of diploid males in bee populations could largely decrease effective population size through an extinction vortex (Zayed and Packer 2005). More studies must be conducted to evaluate the potential of diploid males to copulate with virgin queens and its consequences for the colony and species population. Hence, our findings demonstrate that diploid males of $T$. angustula are able to visit mating aggregations, but due to their rarity, likely have a reduced chance to copulate.

Table I. Genotypes of diploid males of T. angustula (Apidae: Meliponini) found in a reproductive aggregation

\begin{tabular}{lcccccc}
\hline Diploid males & Tang57 & tang03 & tang12 & Tang11 & tang65 & tang60 \\
\hline Male 1 & $158 / 198$ & $219 / 219$ or 219 & $211 / 217$ & $184 / 184$ or 184 & $190 / 194$ & $137 / 147$ \\
Male 2 & $156 / 192$ & $219 / 219$ or 219 & $207 / 211$ & $186 / 190$ & $194 / 210$ & $149 / 149$ or 149 \\
\hline
\end{tabular}




\section{ACKNOWLEDGMENTS}

We thank the Coordenação de Pessoal de Nível Superior (CAPES-PROAP 2010) for financial support and scholarship through the Graduate Program in Zoology of the Departamento de Zoologia-IBUSP; Ademilson Espencer Egea Soares for kindly providing the inventory data of Meliponini nests at the campus da Universidade de São Paulo/Ribeirão Preto/Brazil; Flávio de Oliveira Francisco and Leandro Rodrigues Santiago for helping with molecular techniques and analysis. Authors gratefully acknowledge Rodolfo Jaffé for his critical reading of the manuscript and suggestions

Note scientifique: mâles diploïdes lors des rassemblements de mâles de l'abeille sans aiguillon, Tetragonisca angustula (Apidae: Meliponini)

\section{Eine wissenschaftliche Notiz über diploide Männchen in der Reproduktionsbiologie einer eusozialen Biene}

\section{REFERENCES}

Alves, D.A., Imperatriz-Fonseca, V.L., Francoy, T.M., SantosFilho, P.S., Billen, J., Wenseleers, T. (2011) Successful maintenance of a stingless bee population despite a severe genetic bottleneck. Conserv. Genet. 12, 647-658

Borges, A.A., Ferreira-Caliman, M.J., Nascimento, F.S., Campos, L.A.O., Tavares, M.G. (2012) Characterization of cuticular hydrocarbons of diploid and haploid males, workers and queens of the stingless bee Melipona quadrifasciata. Insect. Soc.. doi:10.1007/s00040-012-0242-x

Brito, R.M., Francisco, F.O., Domingues-Yamada, A.M.T., Gonçalves, P.H.P., Pioker, F.C., Soares, A.E.E., Arias, M.C. (2009) Characterization of microsatellite loci of Tetragonisca angustula (Hymenoptera, Apidae, Meliponini). Conserv. Genet. Resour. 1, 183-187

Cameron, E.C., Franck, P., Oldroyd, B.P. (2004) Genetic structure of nest aggregations and drone congregations of the southeast Asian stingless bee Trigona collina. Mol. Ecol. 13, 2357-2364

Cook, J.M., Crozier, R.H. (1995) Sex determination and population biology in the Hymenoptera. Trends Ecol. Evol. 10, 281-286
Cournault, L., Aron, S. (2009) Diploid males, diploid sperm production, and triploid females in the ant Tapinoma erraticum. Naturwissenschaften 96, 1393-1400

Darvill, B., Lepais, O., Woodall, L.C., Goulson, D. (2012) Triploid bumblebees indicate a direct cost of inbreeding in fragmented populations. Mol. Ecol. 21, 3988-3995

Francini, I.B., Nunes-Silva, C.G., Carvalho-Zilse, G.A. (2012) Diploid male production of two Melipona bees (Hymenoptera: Apidae). Psyche. doi:10.1155/2012/484618

Kerr, W.E., Zucchi, R., Nakadaira, J.T., Butolo, J.E. (1962) Reproduction in the social bees (Hymenoptera: Apidae). J. New York Entomol. Soc. 70, 265-276

Konovalov, D.A., Manning, C., Henshaw, M.T. (2004) Kingroup: a program for pedigree relationship reconstruction and kin group assignments using genetic markers. Mol. Ecol. Notes 4, 779-782

Kraus, F.B., Weinhold, S., Moritz, R.F.A. (2008) Genetic structure of drone congregations of the stingless bee Scaptotrigona mexicana. Insect. Soc. 55, 22-27

Liebert, A.E., Johnson, R.N., Switz, G.T., Starks, P.T. (2004) Triploid females and diploid males: underreported phenomena in Polistes wasps? Insect. Soc. 51, 205-211

Nogueira-Neto, P. (1954) Notas bionômicas sobre meliponíneos III-sobre a enxameagem. Arq. Mus. Nac. 42, 419-452

Paxton, R.J. (2000) Genetic structure of colonies and a male aggregation in the stingless bee Scaptotrigona postica, as revealed by microsatellite analysis. Insect. Soc. 47, 63-69

Peters, J.M., Queller, D.C., Imperatriz-Fonseca, V.L., Roubik, D.W., Strassmann, J.E. (1999) Mate number, kin selection, and social conflicts in stingless bees and honey bees. Proc. Roy. Soc. Lond. B 266, 379-384

Sommeijer, M.J., Bruijn, L.L.M. (1995) Drone congregations apart from the nest in Melipona favosa. Insect. Soc. 42, $123-127$

Van Veen, J.W., Sommeijer, M.J. (2000) Observations on gynes and drones around nuptial flights in the stinglees bees Tetragonisca angustula and Melipona beecheii (Hymenoptera, Apidae). Apidologie 31, 47-54

Van Veen, J.W., Sommeijer, M.J., Meeuwsen, F. (1997) Behaviour of drones in Melipona (Apidae, Meliponinae). Insect. Soc. 44, 435-447

Walsh, P.S., Metzger, D.A., Higuchi, R. (1991) Chelex 100 as a medium for simple extraction of DNA for PCR-based typing from forensic material. Biotechniques 10, 506-513

Whiting, P.W. (1943) Multiple alleles in complementary sex determination of Habrobracon. Genetics 28, 365-382

Zayed, A., Packer, L. (2005) Complementary sex determination substantially increases extinction proneness of haplodiploid populations. Proc. Natl. Acad. Sci. 102, 10742-10746 